\title{
Molecular Identification of Phosphate-Solubilizing Yeast Isolate KR.1BP.4 From Citatah Karst Area
}

\author{
Anggita Rahmi Hafsari ${ }^{1}$, FirdaRizkyKhoerunnissa ${ }^{2}$ \\ \{anggitarahmi@uinsgd.ac.id ${ }^{1}$ \} \\ Biology Department, Faculty of Science and Technology \\ Universitas Islam Negeri SunanGunung Djati Bandung, Jl. A.H. Nasution 105 Bandung ${ }^{1,2}$
}

\begin{abstract}
Citatah Karst Area has diverse microorganisms, including phosphatesolubilizing yeasts. Phosphate-solubilizing yeasts in the soil play an important role in solubilizing organic phosphates into inorganic ones absorbable by plants for photosynthetic process and root development. Phenotypical and biochemical identification of phosphate-solubilizing yeast isolate KR.1BP.4 has been reported, but molecular identification should be performed to ensure accurate results. The aim of this research was to identify the species of phosphate-solubilizing yeast isolate KR.1BP.4. This research was carried out by a descriptive method using the following ITS primers: forward primer ITS1(5'-TCC GTA GGTGAACCTGCG G-3') and reverse primerITS4 (5'-TCCTCCGCT TAT TGA TAT GC-3'). The method consisted of three stages, namely extraction with Genomic DNA Mini Kit (Blood and Cultured cell), PCR with KAPA2G Robusta PCR MasterMix, and electrophoresis and sequencing. Data analysis was performed using BLAST, and alignment was performed using MEGA 6.0. The phosphate-solubilizing yeast isolate KR.1BP.4 was identified as Trichosporonasahiiwith an ITS fragment length of $774 \mathrm{bp}$. Based on the phylogenetic tree and genetic distance, the $T$. asahiiisolate KR.1BP.4 had the closest relatedness with $T$. asahiistrain V9, $T$. asahii strain V3, T. asahiiYCH116, T. asahiiKDLYL 4-1, T. asahiiV1, T. asahiiAP.MSU6, and T. asahii PMM08-1100L at a distance value of $0 \%$. From this research, it can be concluded that the isolate KR.1BP.4 belongs to the species Trichosporonasahii.
\end{abstract}

Keywords: Internal Transcribed Spacer (ITS), Karst, Phosphate, Yeast, Trichosporonasahii, PCR

\section{Introduction}

Karst areas are rarely encountered for its lengthy formation time. The formation of karst areas through dissolution process may cause degradation which takes place at a very slow rate. The degradation rate varies depending on the air temperature and annual rainfall [1]. Citatah Karst Area, Rajamandala spans $27 \mathrm{~km}$ from Rajamandala (adjacent to the Regency of Bandung Barat, Cianjur) to Padalarang [2]. Given the rarity of karst encounter, it is necessary to conduct research on Citatah Karst Area to make the best use of its potentials. According to Yondri [3], Pawon Cave that sits within Citatah Karst Area is rich of phosphategenerated from bat guano sedimentation that is potential to be used as organic fertilizer.

Guano phosphate is composed of nitrogen $(\mathrm{N})$, phosphate $(\mathrm{P})$, calcium $(\mathrm{Ca})$ and a little potassium $(\mathrm{K})$, magnesium $(\mathrm{Mg})$, and sulphur $(\mathrm{S})$ [4]. Phosphate $(\mathrm{P})$ plays a significant role in 
photosynthesis process and root development, but it is available in a meagre amount, usually less than $0.01 \%$ of the total phosphate $(\mathrm{P})$, and it is mostly bound to soil colloids, thereby unabsorbable by plants [5]. Phosphate-solubilizing microorganisms, therefore, are needed for phosphate solubilization [6].

The aim of this research was to identify the species of the isolate KR.1BP.4t hrough molecular method using ITS (internal transcribed spacer). The isolate KR.1BP.4 was identified phenotypically and biochemically. However, phenotypical and biochemical identification comes with some shortcomings. For example, not all strains of certain species have general characteristics, and biochemical tests are not optimal in identification as little changes can affect the outcomes [7]. Moreover, the same strain may exhibit varying characteristics at every reiteration of test [8]. Other instances are that existing databases or guidebooks do not list appropriate species and that test results will depend on every individual's expertise and interpretation, providing non-objective and unclear results [9]. For the reasons described above, a further, focused identification of the isolate KR.1BP.4 from Citatah Karst Area using internal transcribed spacer (ITS) is deemed necessary.

The use of molecular technique in organism identification is advantageous in that the results can be obtained faster and in a higher accuracy, and in the case of microbes, this technique can cover all types of microbes, including the uncultured ones. Fungi are eukaryotic organisms that have conserved regions flanking 18S, 5.8S, and 28S rRNA genes [10]. Amidst the encoding genes, there lies ITS (internal transcribed spacer) in the fungi rDNA.

ITS refers to a region of non-coding DNA, which is an RNA sequence derived from prime transcription process that takes place between ribosomal subunit precursors and removed during splicing process when RNA precursor marker of molekul structural is processed into ribosom. Eukariotic organisms have two ITS: ITS1, which is located between $18 \mathrm{~S}$ and $5.8 \mathrm{~S}$ genes, and ITS2, which is located between $5.8 \mathrm{~S}$ and $28 \mathrm{~S}$ genes. The three ribosomal genes have an extremely high conservation degree [10]. 5.8S gene is only applicable in the identification to phylum and class levels, while $28 \mathrm{~S}$ gene have a higher variety of nucleotide as compared with $18 \mathrm{~S}$ and $5.8 \mathrm{~S}$ genes, allowing it to be applicable in the identification to genus and special levels [11].

ITS, a non-coding region, has higher rates of mutation as compared with coding regions (SSU, 5.8S, and LSU) [12], permiting a wide variety of nucleotide sequences for every species [13]. Sequences of ITS region are highly variable between species, allowing them to be used in yeast identification to species level [14] and even in the identification of some closely related yeast species [12]. ITS is miniscule, approximately $700 \mathrm{bp}$ in size, and has a great number of copies in the core genome. In yeast group, ITS exhibits more effective results than do other sequences and is a recommended universal DNA barcode marker for all fungi in the consortium barcode of life (CBOL). ITS sequences might also be used for protists [15].

\section{Materials And Methods}

\subsection{Material}

\section{Isolate}

Isolate KR.1BP.4 obtained from Genetic and Molecular Laboratory, Isolated From Citatah Karst Area. 


\section{Media}

Pikovskaya agar.

\section{Methods}

DNA extractionwas done using Genomic DNA Mini Kit (blood and cultured cell) (RBC lysis buffer, GT buffer, GB buffer, W1 buffer, wash buffer, elution buffer, GD column, and collection tube $2 \mathrm{ml}$ ) and zymolase per yeast DNA isolation procedure from the Genomic DNA Mini Kit (blood and cultured cell) protocol.

Amplification was conducted using PCR with KAPA2G Robusta PCR master mix (KAPA2G Robusta HotStar, KAPA2G buffer A, KAPA2G buffer B, KAPA2G GC buffer, KAPA enhancer, KAPA $\mathrm{MgCl} 2$, KAPA dNTP mix), forward primer ITS1(5'-TCC GTA GGTGAACCTGCG G-3') andreverse primerITS4 (5'-TCCTCCGCT TAT TGATAT GC-3') (Sugita et al.,1998) per ITS1 and ITS4 fragment amplification procedure from the KAPA2G Robusta PCR master mix protocol.

A PCR cycle consisted of pre-determination at $95 \mathrm{oC}$ for 5 minutes, denaturation at 94 oC for 15 seconds, annealing at $52^{\circ} \mathrm{C}$ for 15 seconds, extension at $72{ }^{\circ} \mathrm{C}$ for 15 seconds, and completion at $72{ }^{\circ} \mathrm{C}$ for 3 minutes. PCR was performed for 35 cycles. Electrophoresis using $1 \%$ agarose at $100 \mathrm{~V}$ for 1 hour.

\subsubsection{Data Analysis}

PCR result was sequenced using the service provided by $1^{\text {st }}$ BASE Malaysia. From the sequencing, raw data were obtained and processed using the program BLAST (Basic Local Alignment Search Tool) by comparing them against the sequences listed on GenBank by the National Centre for Biotechnology Information (NCBI) (http://www.ncbi.nlm.nih.gov) based on which a phylogenetic tree was generated and the genetic distance was calculated using the application MEGA6 [16].

\section{RESULTS}

\section{Result from Molecular Identification}

IsolateKR.1BP.4 from Citatah Karst Area.

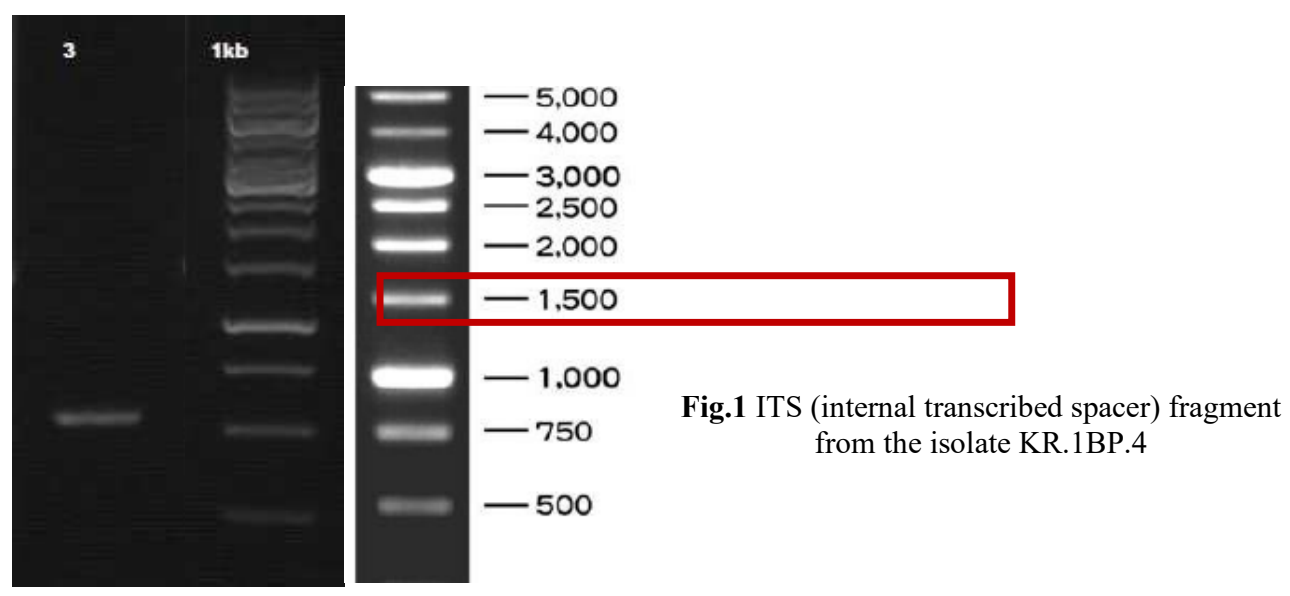


From the electrophoresis, it was found that the ITS fragment of the isolate KR.1BP.4 was 774 bp long with a bright, thick ribbon and an absence of smear (fire type).

\section{Result from Sequencing}

The sequencing result shows the nucleotide sequence:

GCGTTCAAAGATTCGATGATTCACTGAATTCTGCAATTCACATTACTTATCGCAAT TCGCTGCGTTCTTCATCGATGCGAGAGCCAAGAGATCCGTTGTTGAAAGTTTTATT TTGTTATAATAAAACGACGTTCATTACACATTGTTTGTAAAAATACTCGACTTGCG TCAAGTAGTAGAACAGTTCACAGGTGTAAGTGGATATAGTTATAAGCCTATAAAG GCAATCACTAATGATCCTTCCGTAGGTGAACCTGCGGAAGGATCATTAGTGATTG CCTTTATAGGCTTATAACTATATCCACTTACACCTGTGAACTGTTCTACTACTTGA CGCAAGTCGAGTATTTTTACAAACAATGTGTAATGAACGTCGTTTTATTATAACAA AATAAAACTTTCAACAACGGATCTCTTGGCTCTCGCATCGATGAAGAACGCAGCG AATTGCGATAAGTAATGTGAATTGCAGAATTCAGTGAATCATCGAATCTTTGAAC GCAGCTTGCGCTCTCTGGTATTCCGGAGAGCATGCCTGTTTCAGTGTCATGAAATC TCAACCACTAGGGTTTCCTAATGGATTGGATTTGGGCGTCTGCGATTTCTGATCGC TCGCCTTAAAAGAGTTAGCAAGTTTGACATTAATGTCTGGTGTAATAAGTTTCACT GGGTCCATTGTGTTGAAGCGTGCTTCTAATCGTCCGCAAGGACAATTACTTTGACT CTGGCCTGAAATCAGGTAGGACTACCCGCTGAACTTAAGCATATCAATAA

\section{Phyologenetic Tree Resulted}

\begin{tabular}{|c|c|c|c|c|c|c|c|c|c|c|}
\hline & 1 & 2 & 3 & 4 & 5 & 6 & 7 & 8 & 9 & 10 \\
\hline \multicolumn{11}{|l|}{ 1.KR, IBP, 4} \\
\hline 2. Trichosporon asshi istrain V9 & 0.000 & & & & & & & & & \\
\hline 3. Trichosporon asshi stain AMC779 & 0.0020 & 0.002 & & & & & & & & \\
\hline 4. Trichosporon ashhi stran V3 & 0.0000 & 0.000 & 0.002 & & & & & & & \\
\hline 5. Trichosporon aschi isolte NS-1 & 0.0020 & 0.002 & 0.000 & 0.002 & & & & & & \\
\hline 6. Trichosporon asshi strain YCH116 & 0.0000 & 0.000 & 0.002 & 0.000 & 0.002 & & & & & \\
\hline 7. Trichosporon ashhi isolate KDLY.4-1 & 0.0000 & 0.000 & 0.002 & 0,000 & 0,002 & 0.000 & & & & \\
\hline 8. Trichosporon asshi istain V! & 0.0000 & 0.000 & 0.002 & 0.000 & 0,002 & 0.000 & 0,000 & & & \\
\hline 9. Trichosporon asshi strain AP.MSUG & 0.0000 & 0.000 & 0.002 & 0.000 & 0.002 & 0.000 & 0.000 & 0.000 & & \\
\hline \multirow{4}{*}{ 10. Trichossporon asshi istain PMMO8-1100. isolate ISHAM-TS_.DMTIS2711 } & 0.0000 & 0.000 & 0.002 & 0.000 & 0.002 & 0.000 & 0.000 & 0.000 & 0.000 & \\
\hline & & thosporon & on asahii s & $i$ strain $P$ & PMM08-1 & -1100 L is & isolate is & SHAM-TS & TS_ID MIT & rs2711 \\
\hline & $\perp^{\text {Tricho }}$ & chosporon & on asahii s & istrain $A$ & AMC779 & & & & & \\
\hline & & chosporon & on asahii i & i isolate I & e NS-1 & & & & & \\
\hline
\end{tabular}

Phylogenetic tree respresentsKR.1BP.4 as Trichosporonasahiiat a boostrapping value of $65 \%$. 
Fig 3. Isolate KR.1BP.4 has the shortest genetic distance ( $0 \%$ ) from $T$. asahiistrain V9, $T$. asahiistrain V3, T. asahiiYCH116, T. asahiiKDLYL 4-1, T. asahii V1, T. asahii AP MSU6, and T. asahiiPMM08-1100L and the longest genetic distance (0.2\%) from T. asahii AMC779 and T. asahii isolate NS-1.

\section{Discussion}

From the electrophoresis, it was found that the ITS (internal transcribed spacer) fragment derived from KR.1BP.4 was 774 bp long, bright and thick, and had no smear (fire type). DNA fragments of Trichosporonasahii are 250-1,000 bp long [17]. Trichosporonasahii was found to have 500-bp-long fragments[18]. Meanwhile, DNA fragments in ITS region are normally $300-900 \mathrm{bp}$ in length [19].

The bootstrapping value in the phylogenetic tree was $65 \%$. This suggests poor stability as according to Osawa [20], bootstrap is performed to evaluate the stability of a branch, where a branch is said to be stable if the bootstrapping value exceeds $95 \%$ and unstable if the value stands below 70\%. KR.1BP.4 was at the shortest genetic distance (0\%) from T. asahii strain V9, T. asahii strain V3, T. asahii YCH116, T. asahii KDLYL 4-1, T. asahii V1, T. asahii AP MSU6, and T. asahii PMM08-1100L and the longest genetic distance (0.2\%) from T. asahii AMC779 and T. asahii isolate NS-1. According to Tamura [21], these distance values are reliable because a distance value is usable if it stands below $3 \%$.

Trichosporon asahii yeasts, which belong to the genus Trichosporon, are characterized by cream color in the colony's morphology, moist or dry texture, and either the presence or absence of flour coating [12]. They have hyphae and are rich of arthroconidia. Some of them also have clavate and globose. Sometimes appresorria, sarcinae, fused form of a big cell, and endoconidia are also spotted in them. The hyphae have septa, which may or may not be accompanied by tubular or vesicular parethesome.

T. asahiiis a yeast pathogen most commonly associated with clinical specimens such as urine, peritoneal fluid, saliva or phlegm, soft tissues, catheter case, and the tip of catheter tube identified using PCR [22]. It is also found to be the most responsible for trichonosporonosis [23]. T. asahii has the capability of transmitting trichonosporonosis and infecting patients with acute myeloblastic leukemia [24]. From the molecular identification performed by El-Mashad et al.[25], 13 of 16 samples from fragments of nail and skin were found to contain T. asahii which was the clinical cause of most trichosporonosis cases. T. asahii was also found in the houses of patients with summer-type hypersensitivity pneumonitis (SHP) [18]. T. asahii was reported to have infected the skin of lower extremity in immune competent patients without any slight symptom, leading to the assumption that $T$. asahii possibly attacks normal flora on the skin [26]. T. asahii implication as a pathogen that attacks cancer patients has been reported to increase within the last $10-15$ years, but $T$. asahii infections are not restricted to only cancer and neutropenia patients because they are categorized as opportunistic yeast infections and trichonosporonosis has appearance skin to candidiasis [27]. Aside from clinical specimens or body tissues, $T$. asahii is also present in natural environments, especially in the soil. Over the course of the research, the environmental condition was hot and humid, which was suitable for 
Trichosporongrowth [28]. Not only as a pathogen, T. asahii was found in a study to be able to produce $104 \mathrm{U} / \mathrm{mL}$ of lipase, which is useful in biotechnology sector [29]. In addition, the $T$. asahii which is isolated from the petroleum-contaminated soil has the capability of producing biosurfactant on a mineral salt medium that contains diesel oil as a carbon source and is efficient in degrading diesel oil (95\%)[30].

\section{Conclusion}

Based on molecular identification using ITS (Internal Transcribed Spacer), isolate KR.1 BP.4 isolated from Citatah karst area identified as Trichosporon asahii with 774 bp fragment length. Kinship of isolate KR.1 BP.4 with T. asahii strain V9, T. asahii strain V3, T. asahii YCH116, T. asahii KDLYL 4-1, T. asahii V1, T. asahii AP.MSU6, T.asahii PMM08-1100L with a distance value of $0 \%$.

\section{References}

[1] T. Adji and E. Haryono, "Kawasan karst dan prospek pengembangannya di indonesia," no. November, 2015

[2] C. C. M. Rajamandala, "Pengelolaan berkelanjutan kawasan karst citatah - rajamandala," Reg. Vol. III. No. 2 Sept. 2011, 2011.

[3] L. Yondri, "Potensi Arkeologi di Gunung Pawon dan Sekitarnya (Permasaiahan dan Peluangnya dalam Pengelolaan dan Pelestarian)," PURBAWIDYA J. Penelit. dan Pengemb. Arkeol., 2016.

[4] K. Idris, "Potential and Possibility of Direct Use of Guano as Fertilizer in Indonesia," J. Ilmu Tanah Lingkung., vol. 9, no. 1, pp. 37-43, 2007.

[5] E. Ginting, R., C., B., Saraswati, R., dan Husen, "Mikroorganisme Bakteri Pelarut," balittanah litbang pertanian, 1994. .

[6] H. M. Salih, A. I. Yahya, A. M. Abdul-Rahem, and B. H. Munam, "Availability of phosphorus in a calcareous soil treated with rock phosphate or superphosphate as affected by phosphatedissolving fungi," Plant Soil, 1989.

[7] M. Kilian, L. Mikkelsen, and J. Henrichsen, "Taxonomic study of viridans streptococci: Description of Streptococcus gordonii sp. nov. and emended descriptions of Streptococcus sanguis (White and Niven 1946), Streptococcus oralis (Bridge and Sneath 1982), and Streptococcus mitis (Andrewes and Horder," Int. J. Syst. Bacteriol., 1989.

[8] G. Tardif, M. C. Sulavik, G. W. Jones, and D. B. Clewell, "Spontaneous switching of the sucrose-promoted colony phenotype in Streptococcus sanguis," Infection and Immunity. 1989.

[9] P. P. Bosshard, S. Abels, M. Altwegg, E. C. Böttger, and R. Zbinden, "Comparison of Conventional and Molecular Methods for Identification of Aerobic Catalase-Negative GramPositive Cocci in the Clinical Laboratory," J. Clin. Microbiol., 2004.

[10] E. A. Gomes, M. C. M. Kasuya, E. G. de Barros, A. C. Borges, and E. Fernandes de Araújo, "Polymorphism in the internal transcribed spacer (ITS) of the ribosomal DNA of 26 isolates of ectomycorrhizal fungi," Genetics and Molecular Biology. 2002.

[11] J. Guarro, J. Gené, and A. M. Stchigel, "Developments in fungal taxonomy," Clin. Microbiol. Rev., 1999.

[12] C. p. Kurtzman, J. W. Fell, and T. Boekhout, The Yeasts. 2011.

[13] D. E. Ciardo, G. Schär, E. C. Böttger, M. Altwegg, and P. P. Bosshard, "Internal transcribed spacer sequencing versus biochemical profiling for identification of medically important yeasts," J. Clin. Microbiol., 2006.

[14] S. A. James, M. D. Collins, and I. N. Roberts, "Use of an rRNA internal transcribed spacer region to distinguish phylogenetically closely related species of the genera Zygosaccharomyces 
and Torulaspora," Int. J. Syst. Bacteriol., 1996.

[15] . suparman, "MARKAH MOLEKULER DALAM IDENTIFIKASI DAN ANALISIS KEKERABATAN TUMBUHAN SERTA IMPLIKASINYA BAGI MATA KULIAH GENETIKA (Telaah keilmuan genetika molekuler tumbuhan)," BIOEDUKASI, no. Vol 1, No 1 (2012), 2012.

[16] K. Tamura, G. Stecher, D. Peterson, A. Filipski, and S. Kumar, "MEGA6: Molecular evolutionary genetics analysis version 6.0," Mol. Biol. Evol., 2013.

[17] R. Maria, L. Lemes, J. P. Lyon, L. M. Moreira, and C. G. De Cristo, "Comparison Between Random Amplified Polymorphic Dna and Classic Biochemical and Morphological Tests for Trichosporon Species Identification," no. Soll, pp. 1-4, 2000.

[18] T. Sugita, A. Nishikawa, and T. Shinoda, "Identification of Trichosporon asahii by PCR based on sequences of the internal transcribed spacer regions," J. Clin. Microbiol., 1998.

[19] S. I. Fujita, Y. Senda, S. Nakaguchi, and T. Hashimoto, "Multiplex PCR using internal transcribed spacer 1 and 2 regions for rapid detection and identification of yeast strains," J. Clin. Microbiol., 2001.

[20] S. Osawa, Z.-H. Su, Y. Imura, S. Osawa, Z.-H. Su, and Y. Imura, "Molecular Phylogeny of the Carabinae," in Molecular Phylogeny and Evolution of Carabid Ground Beetles, 2004.

[21] K. Tamura, D. Peterson, N. Peterson, G. Stecher, M. Nei, and S. Kumar, "MEGA5: Molecular Evolutionary Genetics Analysis using Likelihood, Distance, and Parsimony methods. Molecular Biology and Evolution.," prep, 2011.

[22] S. Ahmad, M. Al-Mahmeed, and Z. U. Khan, "Characterization of Trichosporon species isolated from clinical specimens in Kuwait," J. Med. Microbiol., vol. 54, no. 7, pp. 639-646, Jul. 2005.

[23] S. Ruan, J. Chien, and P. Hsueh, “ Invasive Trichosporonosis Caused by Trichosporon asahii and Other Unusual Trichosporon Species at a Medical Center in Taiwan ," Clin. Infect. Dis., 2009.

[24] A. Chowdhary, S. Ahmad, Z. U. Khan, D. C. Doval, and H. S. Randhawa, "Trichosporon asahii as an emerging etiologic agent of disseminated trichosporonosis: A case report and an update," Indian J. Med. Microbiol., 2004.

[25] Noha El-Mashad, "Trichosporon identification methods for isolates obtained from different clinical specimens," African J. Microbiol. Res., 2011.

[26] S. Baka, I. Tsouma, and E. Kouskouni, "Fatal lower limb infection by Trichosporon asahii in an immunocompetent patient," Acta Dermatovenerologica Croat., 2013.

[27] J. R. Ebright, M. R. Fairfax, and J. A. Vazquez, "Trichosporon asahii, a Non- Candida Yeast That Caused Fatal Septic Shock in a Patient without Cancer or Neutropenia ," Clin. Infect. Dis., 2001.

[28] T. Sugita, A. Nishikawa, R. Ikeda, and T. Shinoda, "Identification of medically relevant Trichosporon species based on sequences of internal transcribed spacer regions and construction of a database for Trichosporon identification," J. Clin. Microbiol., 1999.

[29] S. S. Kumar and R. Gupta, "An extracellular lipase from Trichosporon asahii MSR 54: Medium optimization and enantioselective deacetylation of phenyl ethyl acetate," Process Biochem., 2008.

[30] "Biosurfactant production and diesel oil degradation by yeast species trichosporon asahii isolated from petroleum hydrocarbon contaminated soil," Int. J. Eng. Sci. Technol., 2010. 
